\title{
First Report of Plasmopara viticola causing Downy Mildew Disease on Grapevine in Sudan
}

\author{
Elsayed SM Hamid ${ }^{1}$, Azza SH Abbo ${ }^{2 *}$ and Siddig M El Hassan ${ }^{2}$ \\ ${ }^{1}$ Zadna for Agric, Services Company, Sudan \\ ${ }^{2}$ Department of Crop Protection, Faculty of Agriculture, Sudan \\ *Corresponding author: Azza SH Abbo, Department of Crop Protection, Faculty of Agriculture, Sudan
}

\begin{tabular}{ll}
\hline ARTICLE INFO & ABSTRACT \\
\hline
\end{tabular}

Received: 幽 July 01, 2019

Keywords: Plasmopara viticola; Survey; Incidence; Severity

Published: 蔧 July 09, 2019

Citation: Elsayed SM Hamid, Azza SH Abbo, Siddig M El Hassan. First Report of Plasmopara viticola causing Downy Mildew Disease on Grapevine in Sudan. Biomed J Sci \& Tech Res 19(3)-2019. BJSTR. MS.ID.003307.

\section{Introduction}

Grapevine (Vitis vinifera) is the most widely planted fruit crop with 7.5 million hectares grown throughout the world. They are also one of the most management intensive crops in existence [1]. Grapevine has been introduced to Sudan in 1896. Later, many varieties have been introduced into Sudan by the Horticulture Administration, Ministry of Agriculture. In early 2007 commercial production was established in various locations in the outskirts of Khartoum city [2]. Among important fungal, bacterial and viral infections, downy mildew disease caused by Plasmopara viticola is an extremely serious disease, which has become a real threat to viticulture in many places around the world, particularly under humid and wet weather conditions [3]. Grape downy mildew epidemics have caused tremendous losses of produce over rather large areas, and thus some major economic hardship in several regions of the world [4].

Downy mildew epidemics cause both direct and indirect yield losses. While direct losses result from rotting of shoots, inflorescences, and clusters, leaf damage, on the contrary, is responsible for an indirect yield losses through reduction in the photosynthetic activity of the affected leaves or premature defoliation of vines, which consequently lead to carbohydrates reduction that negatively influences the grape quality, and the reserve accumulation and the plant vigour in the next season $[1,5]$. Survey the occurrence and epidemic development of downy mildew in grapevine was done twice In the winter and kharif (rainy) seasons of 2013 on two grape varieties (Cardinal and Crimson) at two locations in Sudan (Kadaru, $22 \mathrm{~km}$ north of Khartoum, the capital city of Sudan at latitude $15.74^{\circ} \mathrm{N}$ and longitude $32.40^{\circ} \mathrm{E}$ and Taiba [Jabal Awlia] locality $40 \mathrm{~km}$ south of Khartoum city, at latitude $15.36^{\circ} \mathrm{N}$ and longitude $32.53^{\circ} \mathrm{E}$ ).

Characteristic symptoms of downy mildew were observed, these symptoms were: oil spots on the upper surface, in old infection the affected area showed necrotic lesions which were limited by veins. On the corresponding under leaf surface there were delicate white to grayish cottony growth (Figures $1 \& 2$ ). Both the disease incidence and the severity in the winter season were greater at Kadaru fields (50.7\%, 0.93, respectively) than at Taiba vineyard (43.4\%, 0.61, respectively). Conversely, the latter location demonstrated higher disease development (incidence $45.5 \%$ and severity 0.58$)$ in the rainy season, than the former location $(27.4 \%$, 0.25 , respectively) (Figure 3 ). The detection of the pathogen oospores outside the infection periods in winter and the rainy season, respectively, was carried out in the two grape varieties 'Cardinal' and 'Crimson' at Zadna farm in 2013. Infected leaf 
samples were taken randomly from four sites of the grapevine yard. At each site three growing leaves and three dry fallen leaves were collected from three different trees per variety. The samples were examined monthly under the microscope through the remaining periods of the year to detect the pathogen stages (i.e. vegetative and sexual spores).

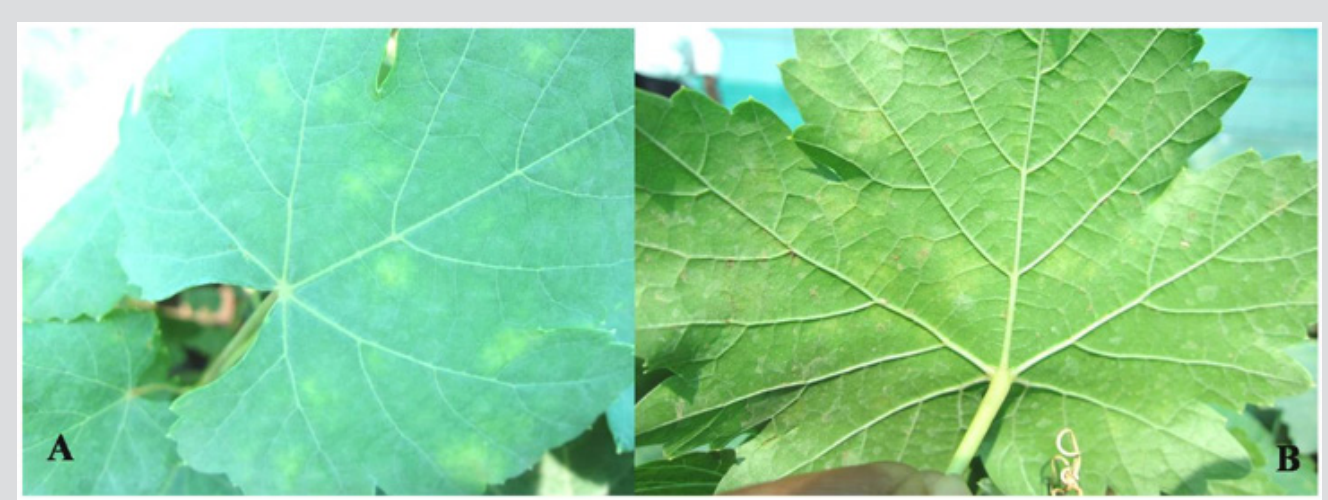

Figure 1: (A) Upper leaf surface showing yellow oil spots symptoms. (B) Lower leaf surface showing whitish to grayish downy mildew corresponding to oil spots.

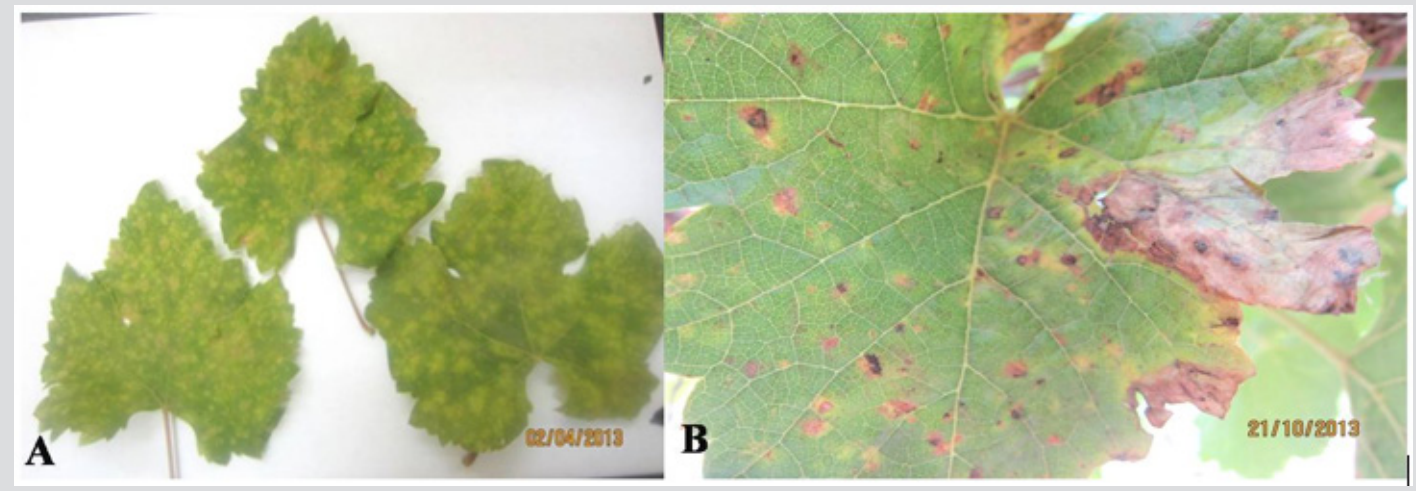

Figure 2: (A) Severely infected leaves. (B) Advanced downy mildew necrotic lesions.

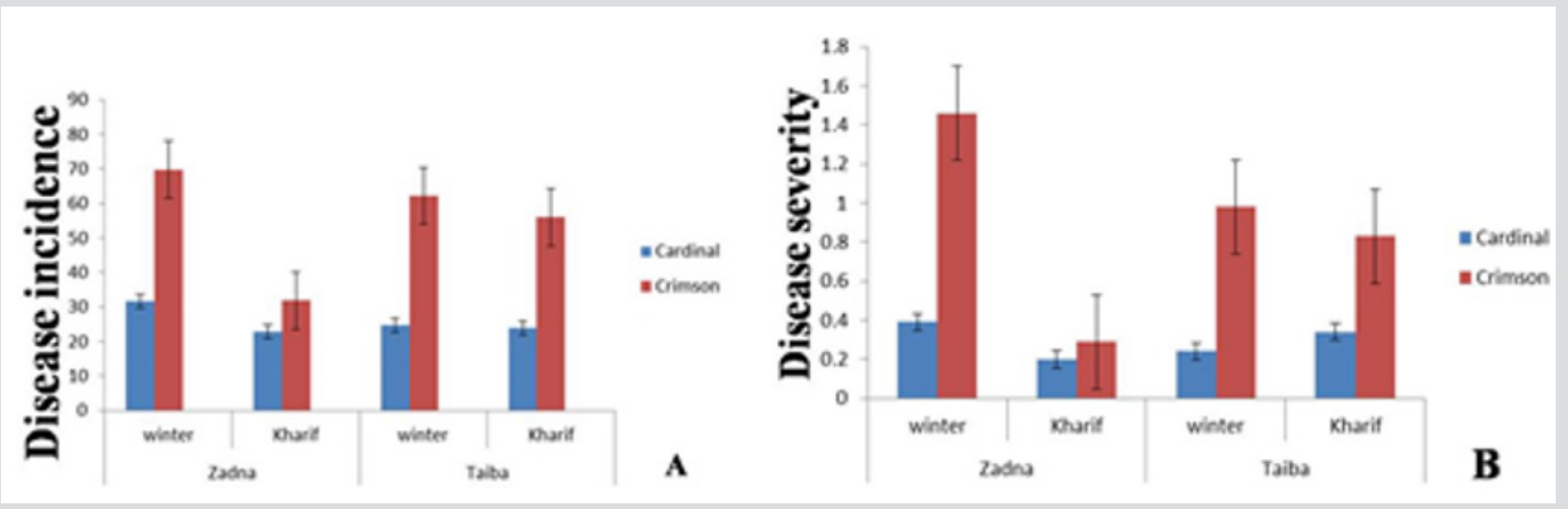

Figure 3: Mean disease incidence (A) and severity (B) in two grapevine varieties in winter and Kharif seasons (2013) at two different locations (Zadna and Taiba) in Khartoum area.

The plastic bag test method was performed according to Fisher et al. [7] to detect the vegetative stage of the pathogen. Newly infected young leaves were removed from the two grape varieties. 'Cardinal' and 'Crimson', and divided into two categories (treatments): a. The leaf sample was contained in a clean plastic bag $(25 \times 15 \mathrm{~cm})$, which was moistened with sterilized distilled water.

b. The leaf sample was kept in a dry plastic bag. 
All leaf samples were incubated under dark condition at 22$25^{\circ} \mathrm{C}$. One leaf from each bag per treatment was inspected and examined under the microscope at intervals of one, two and three days. Slides were prepared from lower leaf sides opposite to oil spots on the upper side. The resting spores (oospores) of Plasmopara viticola were readily observed under the light microscope in the old infected leaf tissue. They displayed different colors ranging from light orange for early stages to dark orange color for mature thickwalled oospores (Figure 4A). Intercellular monopodial branching hyphae, mostly at right angles were seen under the high-power microscope using the bag test. Also, the lemon shaped sporangia were observed (Figure 4B).

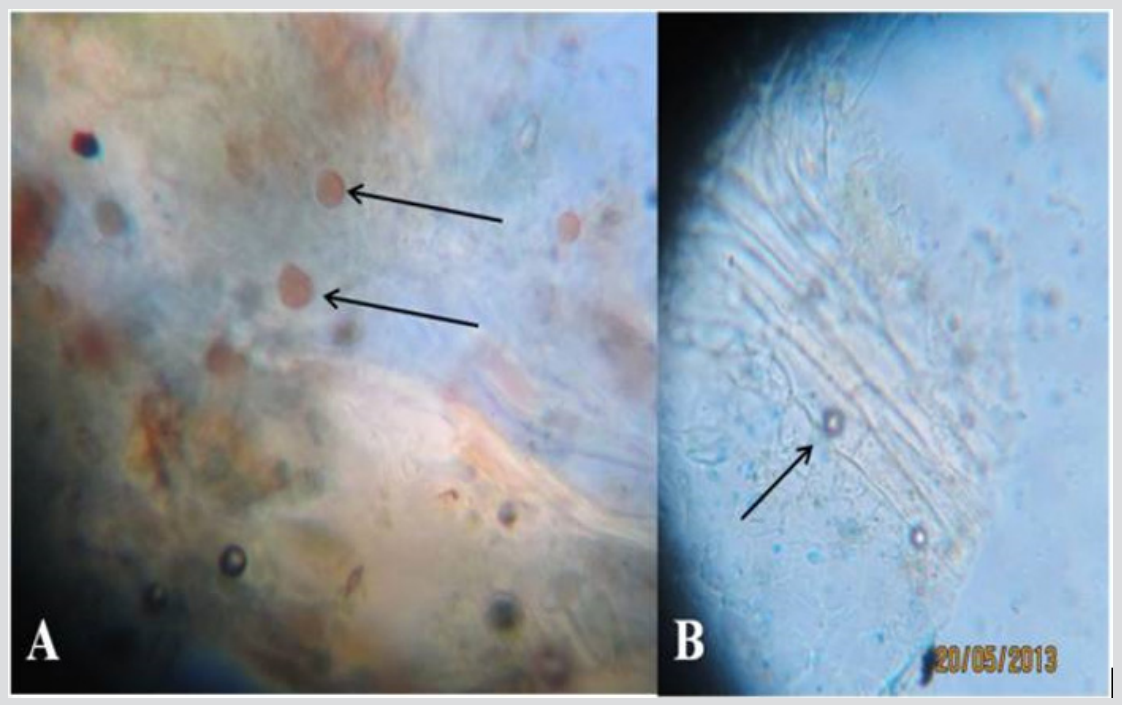

Figure 4: H(A) Oospores of Plasmopara viticola observed under the microscope in old infected leaf tissues. (B) Sporangiophores and sporangia observed under the microscope in the newly infected tissues of the lower surfaces of oils spots symptoms (magnification 400).

\section{References}

1. Wilcox WF, Gubler WD, Uyemoto JK (2015) Compendium of Grape Diseases, Disorders, and Pests. Second Edition. APS Press, St. Paul, MN USA.

2. Osman SA, Elamin OM, Elkashif ME (2009) Effect of training, pruning and harvest time on growth, yield and fruit quality of selected grapevine cultivars under Gezira conditions, Sudan. Gezira Journal of Agricultural Science (Sudan) 7(1): 47-57.

3. Caffi T, Rossi V, Bugiani R, Spanna F, Flamini L, et al. (2009) A model predicting primary infections of Plasmopara Viticola in different grapevine growing areas of Italy. Journal of Plant Pathology 91(3): 535548.

ISSN: 2574-1241

DOI: 10.26717/BJSTR.2019.19.003307

Azza SH Abbo. Biomed J Sci \& Tech Res

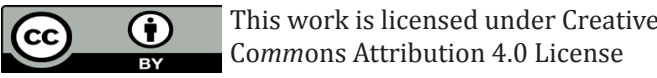

Submission Link: https://biomedres.us/submit-manuscript.php
4. Agrios GN (2005) Plant Pathology. Fifth edition. Academic Press, San Diego, USA.

5. Caffi T, Legler SE, Rossi V, Poni S (2010) Photosynthetic activity in grape leaf tissue with latent, visible and 'virtual' downy mildew lesions $\mathrm{p}$. 204 in: Proc. $6^{\text {th }}$ Int. Workshop Grapevine Downy and Powdery Mildew. Bordeaux, France.

6. Fisher D, Taylor A, Gordon C, Magarey P (2007) Downy mildew in vineyards. Department of Agriculture and Food, Western Australia, Perth. Bulletin 4708.

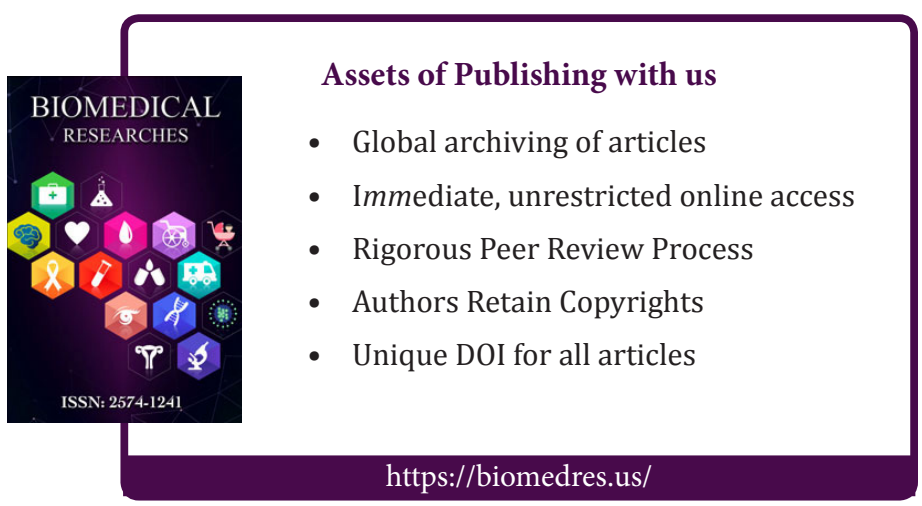

